\section{Chapter}

[8]

\title{
Impacts of invasive alien plant species on biodiversity in the regions of Western Himalayas, India: An overview
}

\author{
Sugam Gupta ${ }^{1,{ }^{*},}$ Naresh Kumar ${ }^{2}$, Devvret Verma ${ }^{3}$, \\ Archana Bachheti ${ }^{4}$, Ashish Kumar Arya ${ }^{4}$, \\ Kamal Kant Joshi ${ }^{5}$ and Rakesh Kumar Bachheti ${ }^{6}$
}

\begin{abstract}
${ }^{1}$ Department of Applied Science, JB Institute of Technology, Dehradun, Uttarakhand, India 2Department of Environmental Science, Sharda University, Greater Noida, Uttar Pradesh, India ${ }^{3}$ Department of Biotechnology, Graphic Era Deemed to Be University, Dehradun, Uttarakhand, India ${ }^{4}$ Department of Environmental Science, Graphic Era Deemed to Be University, Dehradun, Uttarakhand, India

${ }^{5}$ Department of Environmental Science, Graphic Era Hill University, Dehradun, Uttarakhand, India ${ }^{6}$ Department of Industrial Chemistry, Addis Ababa Science and Technology University, Addis Ababa, Ethiopia
\end{abstract}

Abstract

The Western Himalayas regions are one of the riches repositories of the plant diversity in India. The spread of invasive alien plant species across Himalayan range causes loss of biodiversity including species extinction and change in the ecosystem functioning. These exotic plant species differ from their native area, based on their requirements, mode of resource asset and consumption may lead to the change in the structure, profile of the soil as well as the nutrient content. This results in adverse impacts on the biodiversity and ecosystem. However, various studies have been performed in documenting the ecological impacts of invasive species but there is a lack of understanding in regards of their economic importance, medicinal values, and livelihood considerations and in assessment the risk on human health. Present paper showcased some invasive alien species which are common and becoming threat for the forest zones and alpine regions in the Western Himalayan states of India.

Keywords

Biodiversity, Himalayas, Invasive Alien Plant Species, Western Himalayas

$\triangle 7$ Sugam Gupta, Email: sugam2606@gmail.com $\left({ }^{*}\right.$ Corresponding author) (C) 2021 | Agro Environ Media I Agriculture and Environmental Science Academy, Haridwar, India 


\section{Introduction}

The alien plant is also denoted as foreign, introduced, exotic, non-native and non-indigenous. These plant are those which had been introduced by human deliberately or else through human activity or unintentionally from one area to another. This alien plant gets slip away from its environmental habitat and starts its development and reproduction on its own in the regional flora is which considered as naturalized species. The invasive alien species are naturalized alien which has are successful that it can scattered and spread with the regional flora as well as relocate the native biota by threatening the valued environmental, agricultural or personal resources by the damage it causes are considered invasive. Biological interference has been identified as a significant contributor to global environmental change and is a major cause of degradation or depletion of native biodiversity and ecological services. The invasive alien species are plants, animals, or other organisms which come up to places outside their natural area giving a negative impact. It has seen for the past few years that invasive alien plant species have caused several menaces to the native biodiversity, ecosystem services and also deteriorated the environmental quality as well as human health (Kueffer, 2017; Jones and McDermott, 2018; Bartz and Kowarik, 2019). The rate of biological colonization has increased in all habitats and environments as human migration and foreign trade have increased. The detrimental effect of invasive species is compounded further by ongoing climate change, which is expected to increase both the extent and severity of biological invasion (Simberloff, 2000).

Biological invasion could also be thought-about as a variety of biological pollution and major factor on international amendment and one in every of the foremost causes of species extinction (Mooney and Drake, 1987). However, notably, in this respect Global Assessment Report on Biodiversity and Ecosystem Services of United Nation and human health (Pyšek and Richardson, 2010; Stone et al., 2018; Jones and McDermott, 2018; Jones, 2019). In this present scenario United Nation an Inter-governmental stage for biodiversity as well as ecosystem services predicted that about nearly, $1 / 5^{\text {th }}$ of the Earth's surface and even total biodiversity hotspots present around the world are in danger due to foreign aggressors (IPBES, 2019). Invasion issue can be more often notices in developed countries as compared with low income nations. Therefore, the hotspots of invasive alien plant species in developed nations includes Australasia, European Union and North America, Asia Pacific and African regions too. Currently, invasive alien plant species professed as main motorist for the biodiversity loss (Seebens et al., 2018; IPBES, 2019). But these invaders are not only responsible for loss of biodiversity there are others drivers too including anthropogenic activities, pollution, habitat fragmentation, climate change, over exploitation are some major threats to natural biodiversity.

India is known as unique 17 mega biodiversity nation of the world. The country has a vast phytogeographical area and edaphic conditions that offers the lush growth for countless fauna and flora (Chaudhry et al., 2011). The country poses diverse ecological conditions which provide a platform for arise of a new alien species. The Himalayas is known for its rich biodiversity and forest ecosystem that provides a high value of environmental service. The region has expanded landforms and climatic zones which uphold a wide range of vegetation (Rana et al., 2010; Khanduri et al., 2017). The various 
change in the climatic conditions and ecological change lead to the infringement of the area by any other new alien species. Raizada et al. (2008) published that CBD known as Convention on Biological Diversity stated that invasive alien plant species is the second largest cause for the loss of biodiversity worldwide and inflicts high prices on forestry, agriculture, and water ecosystems.

The Himalayan mountain range are one of the most endangered and exquisite habitats of the world, consisting of enormous biodiversity that provides significant ecosystem services (Kumar et al., 2020). For last few years' scientists and policymakers has noticed that native diversity is under pressure all over the globe due to foreign invaders which have become greatest threat.In fact, one sixth of the world's ground surface habitat are enormously unsafe due to attack of alien species, which include large part of high income nations and global hotspots diversity (Early et al., 2016). The invasive species are non-indigenous species and they show adverse consequence which can be economically or environmentally especially at those areas where these species are being introduced, either unintentionally or intentionally, outside their distribution pattern (Masters and Norgrove, 2010). Around 0.5-0.7 percent of the world's tree and shrub inhabitants are now a days invasive outside to their native ranges (Richardson and Rejmanek, 2011).Invasive species are regarded as one of the main causes of biodiversity destruction, altering environmental resources and socioeconomic environments through a variety of mechanisms (Rai and Singh, 2020). The Convention on Biological Diversity (1992) identified biological invasion as a major cause of biodiversity loss, ranking second only to habitat depletion and ecosystem degradation.

\section{Status and distribution of invasive plant species in India}

India is known as mega diverse country since it covers 2.4 percent of the global geographical area and accounts about $8 \%$ of the world's species diversity (Khoshoo, 1996).There are about 90,000 animal species and 45,000 wild floras, with just roughly half of the geographical region investigated so far (MoEF, 2008). Nearly $40 \%$ of species considered as alien species are found in India's flora. Due to growing trade and travel via numerous ways, India is a megadiverse country that is rapidly globalizing, putting species at risk of invasion (Saxena, 1991; Singh, 2005). Invasive alien flora and fauna have been identified as a major cause of species extinction and endangerment in freshwater wetlands and aquatic environments. Some of the Indian research revealed that inland environments have a lot of non- native flora and fauna, as well as the ramifications of regional invasion (Arya et al., 2021). Reddy (2008) compiled the first catalogue of invasive alien plant species of India. Khuroo et al. (2012a, b) released a list of 1599 alien plant species belonging to 842 genera and 161 families with their native ranges and invasion status from India. About 471 invasive plant species were compiled by Inderjit et al. (2018). There are very few studies done from Indian Himalayan region on exotic species (Khuroo et al., 2007; Sekar et al., 2012; Jaryan et al., 2013; Sekar et al., 2015). Debnath and Debnath (2017), provided a comprehensive listing different kinds of foreign plant from Tripura, as well as facts on their intrusive life form, status, pattern, habitat, and source of introduction. This type of research, which provides updates on the status of the invasion, would be extremely beneficial in effective management. 
The data on invasive species distribution is crucial for understanding the range of species shifts and comparing them across different time periods. The states of Western Himalayan region i.e. Himachal Pradesh, Jammu and Kashmir and Uttarakhand account 232,192,181 invasive alien species respectively. The studies done by some of the ecologist and taxonomist in Western Himalayan region are Khuroo et al. (2007) complied the invasive flora of Kashmir valley and Kaur et al. (2014) published invasive flora of Jammu. Jaryan et al. (2013); Sekar et al. (2015) listed various kinds of invasive species for Himachal Pradesh. Invasive alien flora of Doon valley was compiled by Negi and Hajra (2007) and updated listing of invasive alien species was published by Sekar et al. (2012).

\section{Proliferation of invasive species in western Himalayan regions}

The most proliferative alien plant species present in Western Himalayan region are listed in the (Table 1). The results revealed that Ageratum conyzoides, Lantana camara and Parthenium hysterophorousare the established invasive alien species that have flourished and effecting the biodiversity from Western to eastern Himalayan regions of India. The species including Argemone Mexicana, Ageratina adenophora, Cassia tora, Rubus neivus and Sapium sebiferum persist and proliferative in a larger area of western Himalayan regions. Therefore, such species should be given more emphasis to the flourished alien species, but also on the such invasive species which till now are not proliferated so that they can be prevented of becoming invasive to the areas. There are few such species which are confined to a certain area or state for example Anthemis cotula which only is reported from Kashmir Valley (Khuroo et al., 2008) and on the other hand S. sebiferum which has shown its proliferation only in Himachal Pradesh (Jaryan et al., 2013).

\section{Influence of invasive plant species}

The above invasive alien species cause a wide range of impact on different classes of diversity, richness, crop fields, loss of nutrient component and environmental services to larger extent (Bhatt et al., 1994; Wilcove et al., 1998; McKee et al., 2004; Reshi et al., 2008; Vila et al., 2010; Huddle et al., 2011). Some of the studies have also shown that due to growth and development of invasive species can lead to genetic variation in regional populace through hybridization and also often obstructs in plant pollination interaction (Vila et al., 2000; Schweiger et al., 2010). The studies done globally on invasive plants has revealed that there is low richness and diversity of local plants in the invaded occupied sites but on other hand it is also increased the primary production in those localities (Vila et al., 2000). Kosaka et al. (2010) reported that previously, the invasive alien plant species proliferate mainly along way side or open forest cover areas or boundaries in the Indian Himalayan region. In the last few decades it has been seen due to fast urbanization through forest range so many of alien species have started occupying woodland and mountainous ecosystems. The investigation and studies done by some of the researches have revealed that these invasive alien plants species pose numerous impacts/ effects on the 


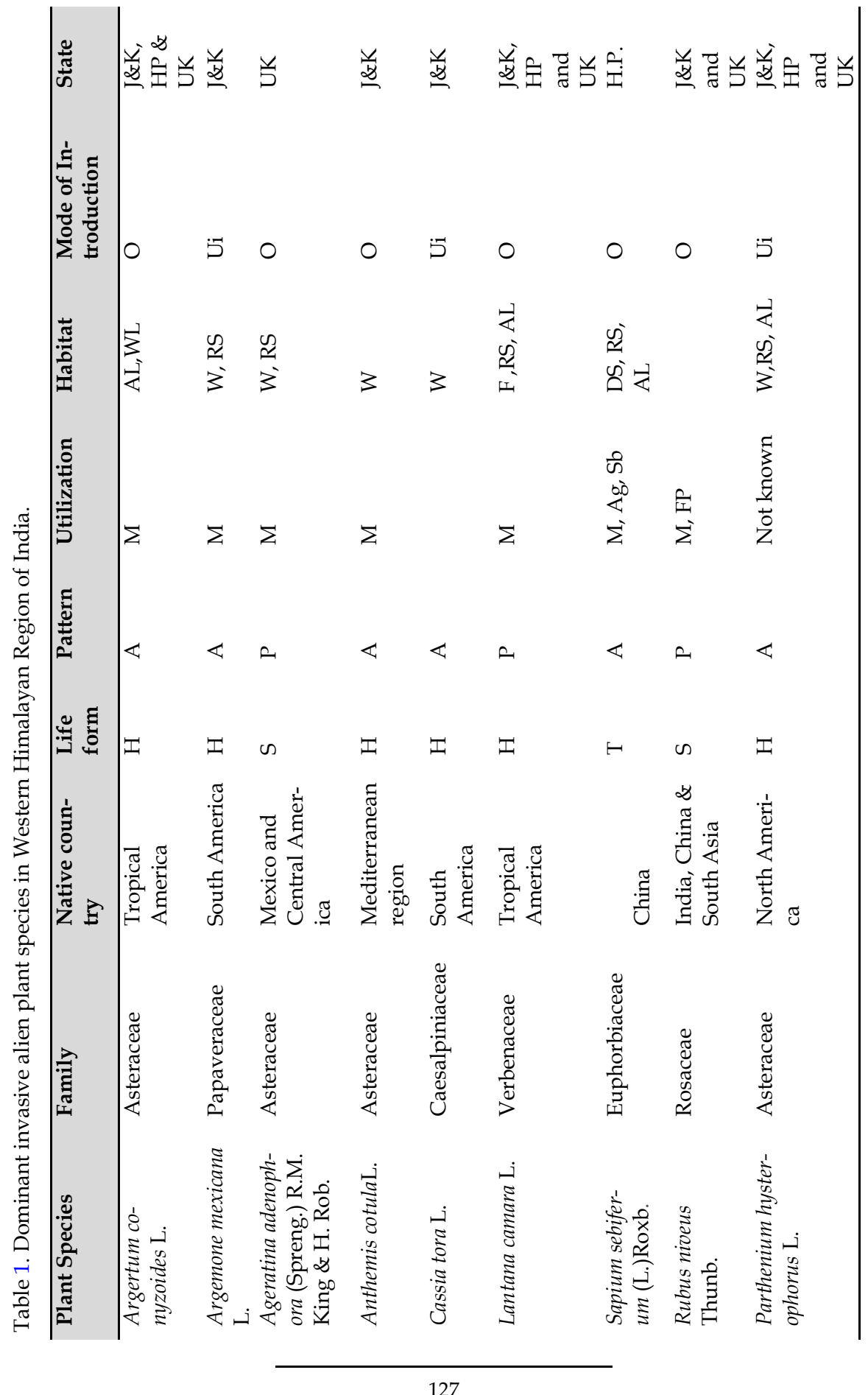


Table 2. Studies on impact or effects of invasive alien species.

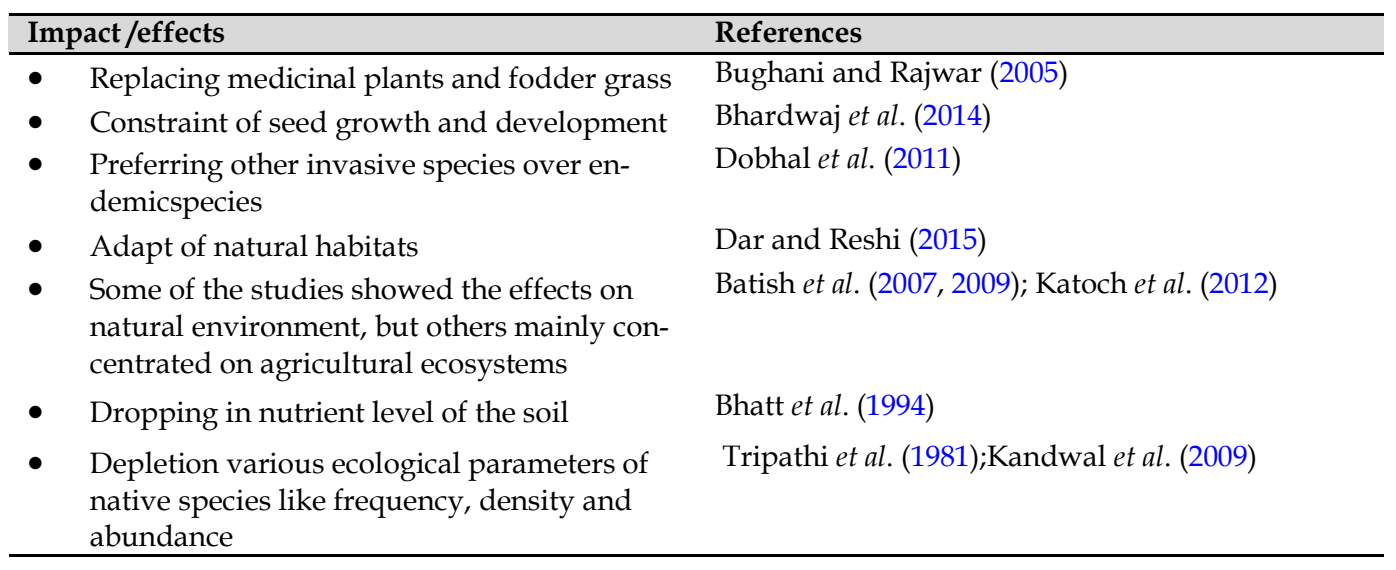

native diversity and ecosystem which are as follows in the Table 2. In Indian mainland is mainly occupied by Parthenium hysterophorous and pest-ridden areas by species which is assessed as nearly 5 million acres (Kohli et al., 2006). Dobhal et al. (2011) reported that Amongst many invasive alien species present in Indian Himalayas viz. A. adenophora, A. conyzoides, L. camara and P. hysterophorus are causing the negative impact on the floral diversity to a higher extent due to wider spread over Indian Himalayan regions. The studies have shown that P. hysterophorus is the one of the toxic or poisonous weed which is supplanting the native population and causing major health related problems in humans in this region. In the same way, the region is also effected by another species.

Lantana camara is stated to infringe upon vast area of lands, particularly in the lower part of Himalayan foothill forests, where it effectively replaces the underground layer of forest vegetation as well as also decrease the growth and development of trees (Kohli et al., 2006; Negi et al., 2013). This toxic wild plant is also responsible for the decrease species richness to $28.4 \%$ of invaded regions and approximately $63 \%$ damage to basal area of vegetation in invaded regions as related to non-invaded whereas, there is negative effect of structural growth and function of plant vegetation (love et al., 2009; Dobhal et al., 2010). Ageratina adenophora species mainly present in the moist areas, along roadside and forests of Garhwal Himalayas and other Himalayan region giving a negative impact on the plant diversity and crop land by increasing advantage through allelopathic affects and to some extent it also changes the soil microbial populations (Dhyani, 1978). Tripathi and Yadav (1982) stated that this invasive species is abundantly found growing in the Eastern Himalayan states. A. adenophorais also reduces the crop production by falling the seed germination of the vegetation, it has also observed that this species is also responsible for the replacement of local grasses from the grassland ecosystems (Kosaka et al., 2010; Katoch et al., 2012; Datta et al., 2017).

Ageratum conyzoides alien species is known to invaded agricultural and crop fields and causing decrease the production of major crops yields by effecting the seed germination; varying soil properties and also responsible in the species reduction in terms of richness in the overspread areas (Kohli et al., 2004; 
Batish et al., 2009, Dogra et al., 2009; Katoch et al., 2012; Sekar et al., 2012). The Kashmir valley known to be one of the biodiversity hotspot of Himalayan region (Allaie et al., 2005), where invasive alien Anthemis cotula is spreading at a faster rate and becoming one of the major threat for the native diversity and environment. The invasion of ruderal habitat by this alien species has made extended conscription pattern abetted by disturbed habitat, favourable physical factors like temperature, moisture, light and nutrient level, high populace size that can be observed even afterward of seedling mortality and allelopathic action of its aqueous foliage percolate (Allaie et al., 2006; Shah and Reshi, 2007). Argemone mexicana is a common alien species found growing everywhere along the roadside in India. The seeds of the plant bear a resemblance to the seeds of mustard (Brassica nigra) it can be adulterated by argemone seeds, rather it is poisonous. There are many important examples of katkar poisoning which have been reported from India as well other countries of the world. There was one such instance with occurred as a major outbreak in India in 1998 where 1\% adulteration of mustard oil was mixed with argemone oil and caused clinical disease (WHO, 2006). Cassia tora is innate to tropical South America and its was introduced in India nearly in initially 1960's (Singh, 1979; Raghavan, 1980; Reddy, 2008). It has been observed in some of the studies that Cassia Spp. usually found growing in scattered clumps, in the interim water logged areas as well as along roadside in pasture land and frequently this species is found growing with the diverse vegetation (Bolde and Dhulap, 2019). Rubus niveus the most dominant alien woody tree species in different regions of India. This species spread speedily and grow faster, utilized accessible resources and influenced larger ecological flexibility than native species in the area (Singh et al., 2006). Sapium sebiferm it is commonly recognized as tallow tree and is also known to be as most trouble invasive tree species in the world. In the Western Himalayan region especially Himachal Pradesh is found growing abundantly and in few areas it can be seen influencing the wetland as well as mesic habitat. As S. sebiferm favours moister areas to increase dominance against innate vegetation (Jubinsky, 1993).

\section{Management outlook of invasive alien species}

In the fifth IUCN World Park Congress (2003) mentioned that management of invasive alien plant species could be a precedence matter and its necessity to be standard into all the aspects that management of the forests additionally as all protected areas. The matter in context of managements of the protected areas was highlighted throughout IUCN World Conservation Congress of 2012 and IUCN World Parks Congress control throughout 2014. The management of invasive species is considered to be expansive and high labour cost which have been an interruption in management of these invasive species. Eradication and biological control studies have shown that eradication methods for invasive species are effective only if they are completed at initial stage of propagation (Zanden et al., 2010). To some extent eradication process of well-established invasive species may be reason for the release of one more earlier suppressed non- invasive species to invade a particular area. Hence, eradication process needs a lot of monitoring of the specific areas where these invasive alien species are proliferating so, further invasion can be prevented (Caut et al., 2009). Whether, invasive alien plant 
species have positive or negative ecosystem services however it ought to be clearly recognized to clarify its cost-benefit which can be useful for the policy makers and stakeholders (Zengeya et al., 2017; Everard et al., 2018; Shackleton et al., 2019). The policy makers need to undergo many aspects of obliteration like price of eradication, likelihood of success and for an instance if failure happens then more what impact can intruder will cause to a selected space that may be regeneration of invasion species, aid different invasive species (Zanden et al., 2010). For eradication of invasive species from Indian Himalaya region a obliteration was done in Jim Corbett National Park, Uttarakhand, with the help of cut root stock methodology beside with manual removal of L. camara, which is one of the a well-established invasive alien species in this region (Love et al., 2009). Further, to stop the regeneration of invasive species or any other secondary invasion by different invasive species, restoration of that area with native grass species was done and this experiment was beneficial (Babu et al., 2009).

Biological control measures are taken in several components of the globe, however not in India aside from toxic Lantana camara. The tries to manage infestation of toxic plant $L$. camara biologically by introduction of pest of the species was initiated in India in 1916 (Muniappan and Viraktamath, 1986). Ever since varied studies/ investigation are directed to manage the species by diverse pests for instance Ophiomyia lantanae, Lantanophaga pusillidactyla, Teleonemia scrupulosa etc., and for these pest the host plant is L. camara (Khan, 1944; Muniappan and Viraktamath, 1986). Invasive alien plants have a plus over the natives as a result of the run off their natural enemies from their native ranges. Thus, biological control of invasive species mistreatment co-evolved natural enemies has long been thought-about a secure, environmentally sound and price effective management tool it's one technique that's used either alone or together with alternative management choices. Moreover, it's usually extraordinarily successful and extremely value effective method (Moran et al., 2005; Messing and Wright, 2006).The systematic study on ecological role of invasive species should be conducted before the eradication process. On the other hand, biological control studies of invasive species cab be beneficial for improved control as well as management of invasive wild plants. Therefore, it requires proper monitoring for an enduring time for better management of the disturbed sites with well-established invasive species since long time with an effective management sustainable approach.

\section{Conclusion}

Among several invasive species including L. camara, A. adenophora, P. hysterophorus and A. conyzoides, $R$. niveus, S. sebiferm, C. tora, A. mexicana and A. cotula have been reported from Indian Himalayan states. These above species proliferated over large areas of India. The printed studies have shown the evidences that fast urbanization in the forms of construction of roads passing though forest and highaltitude ecosystem and extensive tourism in such areas have lead the increase growth rate of these invasive species. The Himalayan regions have rich and unique biodiversity, still it faces sever intimidations due to proliferation of invasive alien species and this evidence shows that these alien species are moving upwards in the higher altitudes of the Himalayan states. Widely distributions and fast proliferation of these species is menace for native biodiversity and ecosystems to the greater extent 
in near future. So, more emphasize must be given on these invasive species and some appropriate management strategies can be made for relating to plant invasion over Indian Himalayan regions. Recent advancement in the technologies like GIS and Remote sensing can help in the study and management of the invasive species. The impact of climate change can also be studied through these techniques.

\section{Acknowledgments}

Authors are thankful to the Department of Applied Science, JB Institute of Technology, Dehradun. Department of Biotechnology; Department of Environment Science, Graphic Era University, Dehradun and Department of Industrial Chemistry, Addis Ababa Science and Technology University, Addis Ababa, Ethiopia.

\section{References}

Allaie, R.R., Reshi, Z. and Wafai, B.A. (2005). Demographic studies on alien invasive Anthemis cotula L. Kashmir Himalaya. Trends Life Science, 20: 49-56.

Allaie, R.R., Reshi, Z, Rashid, I. and Wafai, B.A. (2006). Effect of aqueous leaf leachate of Anthemis cotula-an alien invasive species on germination behaviour of some field crops. Journal of Agronomy and Crop Science, 192(3): 186-191.

Arya, A. K., Joshi, K. K., Bachheti, A. and Rawat, R. (2021). Status and impact of invasive and alien species on environment, and human welfare: an overview. Uttar Pradesh Journal of Zoology, 42(8): 49-58.

Babu, S., Love, A. and Babu, C.R. (2009) Ecological restoration of lantana-invaded landscapes in Corbett Tiger Reserve, India. Ecological Restoration 27(4): 467-477.

Bartz, R. and Kowarik, I. (2019). Assessing the environmental impacts of invasive alien plants: A Review of assessment approaches. Neo Biota, 43: 69.

Batish, D.R., Lavanya, K., Singh, H.P. and Kohli, R.K. (2007). Phenolic allelo-chemicals released by Chenopodium murale affect the growth, nodulation and macromolecule content in chickpea and pea. Plant Growth Regulation, 51(2): 119-128.

Batish, D.R., Kaur, S., Singh, H.P. and Kohli, R.K. (2009). Role of root-mediated interactions in phytotoxic interference of Ageratum conyzoides with rice (Oryza sativa). Flora-Morphology Distribution Functional Ecology of Plants, 204(5): 388-395.

Bhardwaj, S., Kapoor, K.S. and Singh, H.P. (2014). Studies on allelopathic effects of Ageratina adenophora sprengel (King and Robinson) on some weed plants growing in forest ecosystem. International Journal of Theoretical and Applied Sciences, 6 (2): 1-10.

Bhatt, Y.D., Rawat, Y.S. and Singh, S.P. (1994). Changes in ecosystem functioning after replacement of forest by Lantana shrub land in Kumaun Himalaya. Journal of Vegetation Science, 5(1): 67-70.

Bolde, P.M. and Dhulap, V.P. (2019). Impact of Invasive shrub species (Cassia spp.) on Plant Diversity and Insect Abundance in Grasslands from Solapur region. International Journal of Basic and Applied Research, 9 (5): 310-320.

Bughani, I. and Rajwar, G.S. (2005). Primary productivity and the impacts of the exotic weed Eupatorium glandulosum in a montane grassland of Garhwal Himalaya. Environmentalist, 25(1): 31-38.

Caut, S., Angulo, E. and Courchamp, F. (2009). Avoiding surprise effects on Surprise Island: alien species control in a multi trophic level perspective. Biological Invasions, 11(7): 1689-1703.

Chaudhry, P., Dollo, M., Bagra, K. and Yakang, B., (2011). Traditional biodiversity conservation and natural resource management system of some tribes of Arunachal Pradesh, India. Interdisciplinary Environmental Review, 12(4): 338-348.

Convention on Biological Diversity (CBD) (1992). Retrieved from https://www.cbd.int/doc/legal/cbd-en.pdf accessed_on 19 
May,2021.

Crowl, T.A., Crist, T.O., Parmenter, R.R., Belovsky, G. and Lugo, A.E. (2008). The spread of invasive species and infectious disease as drivers of ecosystem change. Frontiers in Ecology and the Environment, 6(5): 238-246.

Dar, P.A. and Reshi, Z.A. (2015). Do alien plant invasions cause biotic homogenization of terrestrial ecosystems in the Kashmir Valley, India? Tropical Ecology, 56(1): 111-123.

Datta, A., Kühn, I., Ahmad, M., Michalski, S. and Auge, H. (2017). Processes affecting altitudinal distribution of invasive Ageratina adenophora in Western Himalaya: the role of local adaptation and the importance of different life-cycle stages. PLoS ONE, 12(11): e0187708.

Debnath, A. and Debnath, B. (2017). Diversity, invasion status and usages of alien plant species in North Eastern hilly state of Tripura: a confluence of Indo-Barman hotspot. American Journal Plant Science, 8(02): 212.

Dhyani, S.K. (1978). Allelopathic potential of Ageratina adenophora on seed germination of Lantana camara var. aculeata. Indian Journal of Forestry, 1(4): 311.

Dobhal, P.K., Kohli, R.K. and Batish, D.R. (2010). Evaluation of the impact of Lantana camara L. invasion, on four major woody shrubs, along Nayar river of Pauri Garhwal, in Uttarakhand Himalaya. International Journal of Biodiversity and Conservation, 2(7): 155-161.

Dobhal, P.K., Kohli, R.K. and Batish, D.R. (2011). Impact of Lantana camara L. invasion on riparian vegetation of Nayar region in Garhwal Himalayas (Uttarakhand, India). Journal of Ecology and the Nature Environment, 3(1): 11-22.

Dogra, K.S., Kohli, R.K. and Sood, S.K. (2009). An assessment and impact of three invasive species in the Shivalik hills of Himachal Pradesh, India. International Journal of Biodiversity Conservation, 1(1): 4-10.

Early, R., Bradley, B.A., Dukes, J.S., Lawler, J.J., Olden, J.D., Blumenthal, D.M., Gonzalez, P., Grosholz, E.D., Iban ez, I., Miller, L.P., Sorte, C.J.B. and Tatem, A.J. (2016). Global threats from invasive alien species in the twenty-first century and national response capacities. Nature Communication, 7: 12485.

European Environment Agency (EEA) (2012) The impacts of invasive alien species in Europe. Technical report No 16/2012. Copenhagen, Denmark, retrieved from http://www.eea.europa.eu/publications/impacts-of-invasive-alien-species accessed on 12 July, 2021.

Everard, M., Gupta, N., Chapagain, P.S., Shrestha, B.B., Preston, G. and Tiwari, P. (2018). Can control of invasive vegetation improve water and rural livelihood security in Nepal?. Ecosystem services, 32: 125-133.

Huddle, J.A., Awada, T., Martin, D.L., Zhou, X., Pegg, S.E. and Josiah, S.J. (2011). Do invasive riparian woody plants affect hydrology and ecosystem processes? Great Plains Research, 21: 49-71.

IPBES (2019): Summary for policymakers of the global assessment report on biodiversity and ecosystem services of the Intergovernmental Science-Policy Platform on Biodiversity and Ecosystem Services. S. Díaz, J. Settele et al. (eds.). IPBES secretariat, Bonn, Germany, pp.56, retrieved from https://ipbes.net/sites/default/files/inline/files/ ipbes_global_assessment_report_summary_for_policymakers.pdf accessed on 18 May, 2021.

Jaryan, V., Uniyal, S.K., Gupta, R.C. and Singh, R.D. (2013). Alien fora of Indian Himalayan State of Himachal Pradesh. Environmental Monitoring and Assessment, 185(7): 6129-6153.

Inderjit Pergl, J., Van Kleunen, M., Hejda, M., Babu, C.R., Majumdar, S., Singh, P., Singh, S.P., Salamma, S., Rao, B.R. and Pyšek, P. (2018). Naturalized alien fora of the Indian states: biogeographic patterns, taxonomic structure and drivers of species richness. Biological Invasions, 20(6): 1625-1638.

Jones, B.A. and McDermott, S.M. (2018). Health impacts of invasive species through an altered natural environment: Assessing air pollution sinks as a causal pathway. Environmental and. Resource. Economics journal, 71(1): $23-43$.

Jones, B.A. (2019). Tree shade, temperature, and human health: evidence from invasive species-induced deforestation. Ecological. Economics, 156: 12-23.

Jubinsky, G. (1993). Chinese tallow gets worse. The Palmetto, 13(3): 1-3.

Kandwal, R., Jeganathan, C., Tolpekin, V. and Kushwaha, S.P.S. (2009). Discriminating the invasive species, 'Lantana' using vegetation indices. Journal of Indian Society of Remote Sensing, 37(2): 275.

Katoch, R., Singh, A. and Thakur, N. (2012). Allelopathic influence of dominant weeds of North-Western Himalayan region on common cereal crops. International Journal of Environment Science, 3: 84-97. 
Khan, A.H. (1944). On the lantana bug (Teleonemia scrupulosa Stal). Indian Journal of Entomology, 6: 149-161.

Khanduri, A., Biswas, S. and Vasistha, H.B. (2017). Forest invasive species assessment study in different village forests of Garhwal Himalaya. International Journal of Current Research and Review, 9(17): 8.

Kaur, B., Bhatia, S. and Sharma, K.K. (2014). Diversity and impact of invasive alien plant species of family Asteraceae in Jammu district (Jammu and Kashmir India). International Journal of Interdisciplinary Multidisciplinary Studies, 1(8): 51-62.

Kosaka, Y, Saikia B, Mingki T, Tag H, Riba T, Ando K (2010). Roadside distribution patterns of invasive alien plants along an altitudinal gradient in Arunachal Himalaya, India. Mountain Research and Development, 30: 252-258.

Khoshoo, T.N. (1996). Biodiversity in the Indian Himalayas: conservation and utilization. In Sheng P (Ed), Banking on Biodiversity, ICIMOD, Kathmandu, pp. 185-255.

Khuroo, A.A., Rashid, I., Reshi, Z., Dar, G.H. and Wafai, B.A. (2007).The alien fora of Kashmir Himalaya. Biological Invasions, 9 (3): 269-292.

Khuroo, A.A., Reshi, Z., Rashid, I., Dar, G.H. and Khan, Z.S. (2008). Operational characterization of alien invasive fora and its management implications. Biodiversity Conservation, 17(13): 3181-3194.

Khuroo, A.A., Reshi, Z.A., Dar, G.H., Hamal, I.A. (2012a). Plant invasions in Jammu and Kashmir state India. In: Bhatt et al (eds) Invasive alien plants: An ecological appraisal for the Indian subcontinent. CABI, Wallingford, 1, pp. 216-226.

Khuroo, A.A., Reshi, Z.A., Malik, A.H., Weber, E., Rashid, I. and Dar, G.H. (2012b). Alien fora of India: taxonomic composition, invasion status and biogeographic affiliations. Biological Invasions, 14(1): 99-113

Kohli, R.K., Dogra, K.S., Batish, D.R. and Singh, H.P. (2004). Impact of invasive plants on the structure and composition of natural vegetation of north Western Indian Himalayas. Weed Technology 18: 1296-1300

Kohli, R.K., Batish, D.R., Singh, H.P. and Dogra, K.S. (2006). Status, invasiveness and environmental threats of three tropical American invasive weeds (Parthenium hysterophorus L., Ageratum conyzoides L., Lantana camara L.) in India. Biological Invasions, 8(7): 1501-1510

Kueffer, C. (2017). Plant invasions in the Anthropocene. Science, 358(6364): 724-725.

Kumar, M., Verma, A.K. and Garkoti, S.C. (2020). Lantana camara and Ageratina adenophora invasion alter the understory species composition and diversity of chir pine forest in Central Himalaya, India. Acta Oecologica, 109: 103642.

Love, A., Babu, S. and Babu, C.R. (2009). Management of Lantana, an invasive alien weed, in forest ecosystems of India. Current Science, 97(10): 1421-1429.

Masters, G and Norgrove, L. (2010). Climate change and invasive alien species. UK: CABI Working Paper, 1.

Mazza, G., Tricarico, E., Genovesi, P. and Gherardi, F. (2014). Biological invaders are threats to human health: an overview. Ethology Ecology \& Evolution, 26(2-3): 112-129.

McKee, J.K., Sciulli, P.W., Fooce, C.D. and Waite, T.A. (2004). Forecasting global biodiversity threats associated with human population growth. Biological Conservation, 115: 161-164.

Messing, R.H. and Wright, M.G. (2006). Biological control of invasive species: solution or pollution? Frontiers in Ecology and the Environment, 4(3): 132-140

Ministry of Environment and Forests (MoEF). (2008). National Biodiversity Action Plan. retrieved from http://envfor.nic.in/ division/csurv/Ap proved NBAP.pdf accessed on 19 May, 2021.

Mooney, H.A. and Drake, J.A. (1987). The ecology of: biological invasions. Environment: Science and Policy for Sustainable Development, 29(5): 10-37.

Moran, V.C., Hofmann, J.H. and Zimmermann, H.G. (2005). Biological control of invasive alien plants in South Africa: necessity, circumspection, and success. Frontiers in Ecology and the Environment, 3(2): 71-77.

Muniappan, R. and Viraktamath, C.A. (1986). Status of biological control of the weed, Lantana camara in India. Tropical Pest Management, 32: 40-42.

Negi, P.S. and Hajra, P.K. (2007). Alien fora of Doon valley, Northwest Himalaya. Current Science, 92(7): 968-978.

Negi, G.C.S., Sharma, S., Vishvakarma, S.C., Samant, S.S., Maikhuri, R.K., Prasad, R.C. and Palni, L.M.S. (2013). Lantana camara in India: an ecological review. GBPIHED publication, Almora.

Pyšek, P. and Richardson, D.M. (2010). Invasive species, environmental change and management, and health. Annual Review of Environment and Resources, 35: 25-55. 
Raghavan, B.S. (1980). Cassia uniflora Mill (Caesalpiniaceae)- a new record for India. Bulletin of Botanical Survey of India, $22: 225$.

Rai, P.K. and Singh, J.S. (2020). Invasive alien plant species: Their impact on environment, ecosystem services and human health. Ecological Iindicators, 111: 106020.

Raizada, P., Sharma, G.P. and Raghubanshi, A.S. (2008). Ingress of Lantana in dry tropical forest fragments: Edge and shade effects. Current Science, 94(2): 180-182.

Rana, J.C., Singh, A., Sharma, Y., Pradheep, K. and Mendiratta, N. (2010). Dynamics of plant bio-resources in Western Himalayan region of India- watershed based study. Current Science, 98(2): 192-203.

Reddy, C.S. (2008). Catalogue of invasive alien fora of India. Life Science Journal, 5(2): 84-89.

Richardson, D.M. and Rejmanek, M. (2011). Trees and shrubs as invasive alien species a global review. Diversity and Distributions 17: 788-809.

Reshi, Z., Rashid, I., Khuroo, A.A. and Wafai, B.A. (2008). Effect of invasion by Centaurea iberica on community assembly of a mountain grassland of Kashmir Himalaya, India. Tropical Ecology, 49: 147-156.

Saxena, K.G. (1991). Biological invasions in the Indian subcontinent: Review of invasion by plants. In: Ramakrishnan PS. (ed.) Ecology of Biological Invasions in the Tropics, S: 53-73.

Schweiger, O. Biesmeijer, J.C., Bommarco, R., Hickler, T., Hulme, P.E., Klotz, S., Kühn, I., Moora, M., Nielsen, A., Ohlemüller, R. and Petanidou, T (2010). Multiple stressors on biotic interactions: how climate change and alien species interact to affect pollination. Biological Review, 85(4): 777-795.

Sekar, K.C. (2012). Invasive alien plants of Indian Himalayan region-diversity and implication. American Journal of Plant Sciences, 3(2): 177.

Sekar, K.C., Manikandan, R. and Srivastava, S.K. (2012). Invasive alien plants of Uttarakhand Himalaya. Proceedings of National Academy of Science India Sect B, 82(3): 375-383.

Sekar, K.C., Pandey, A., Srivastava, S.K., and Giri, L. (2015). Invasive alien plants of Himachal Pradesh, India. Indian Forester. 141(5): 520-527.

Seebens, H., Blackburn, T.M., Dyer, E.E., Genovesi, P., Hulme, P.E., Jeschke, J.M. and Essl, F. (2018). Global rise in emerging alien species results from increased accessibility of new source pools. Proceedings of the National Academy of Sciences, 115 (10): E2264-E2273.

Shackleton, R.T., Shackleton, C.M. and Kull, C.A. (2019). The role of invasive alien species in shaping local livelihoods and human well-being: A Review. Journal of Environmental. Management. 229: 145-157.

Shah, M.A. and Reshi, Z. (2007). Invasion by alien Anthemis cotula L. in a biodiversity hotspot: Release from native foes or relief from alien friends? Current science, 92(1): 21-22.

Singh, N.P. (1979). Cassia sericea Sw. - a New record for India. Bulletin of Botanical Survey of India, 21: 203-205.

Singh, K.P. (2005). Invasive alien species and biodiversity in India. Current Science. 88(4): 539.

Singh, J.S, Singh, S.P. and Gupta, S.R. (2006). Ecology Environment and Resource Conservation. Anamaya Publishers, New Delhi, India, pp. 668

Simberloff, D. (2000). Global climate change and introduced species in United States forests. Science of the total environment, 262 (3): 253-261.

Stone, C.M., Witt AB, Walsh, G.C., Foster, W.A. and Murphy, S.T. (2018). Would the control of invasive alien plants reduce malaria transmission? A Review, Parasites \& vectors, 11(1): 1-18.

Tripathi, R.S., Singh, R.S., Rai, J.P.N. (1981). Allelopathic potential of Ageratina adenophora, a dominant ruderal weed of Meghalaya. Proceedings of Indian Academy of Sciences, 47(3): 458-465.

Tripathi, R.S. and Yadav, A.S. (1982). Population regulation of Ageratina adenophora spreng and E. riparium regel: effect of population density, soil nitrogen and light intensity. Plant Soil, 65(1): 35-49

Vander Zanden, M.J., Hansen, G.J., Higgins, S.N. and Kornis, M.S. (2010). A pound of prevention, plus a pound of cure: early detection and eradication of invasive species in the Laurentian Great Lakes. Journal of Great Lakes Research , 36(1): 199205.

Vilà, M., Weber, E. and Antonio, C.M. (2000). Conservation implications of invasion by plant hybridization. Biological Invasions, (3): 207-217. 
Vilà, M., Basnou, C., Pyšek, P., Josefsson, M., Genovesi, P., Gollasch, S., Nentwig, W., Olenin, S., Roques, A., Roy, D. and Hulme, P.E. (2010). How well do we understand the impacts of alien species on ecosystem services? A Pan-European, cross-taxa assessment. Frontires of Ecology and the Environment, 8(3): 135-144.

Wilcove, D.S., Rothstein, D., Dubow, J., Phillips, A. and Loso, E. (1998). Quantifying threats to imperiled species in the United States. Bioscience, 48: 607-615.

WHO (2006). South East Asia Regional Office. Epidemic dropsy.

WHO (2015) Connecting global priorities: biodiversity and human health. Astate of knowledge review, Geneva, Switzerland, retrieved from https://www.who.int/publications/i/item/connecting-global-priorities-biodiversity-and-humanhealth accessed on 19 May, 2021.

Zengeya, T., Ivey, P., Woordford, D.J., Weyl, O., Novoa, A., Shackleton, R., Richardson, D. and Van Wilgen, B. (2017). Managing conflict-generating invasive species in South Africa: challenges and trade-offs. Bothalia, 47: 2160.

$* * * * *$

Cite this chapter as: Gupta, S., Kumar, N., Verma, D., Bachheti, A., Arya, A.K., Joshi, K.K. and Bachheti, R.K. (2021). Impacts of invasive alien plant species on biodiversity in the regions of Western Himalayas, India: An overview. In: Biological Diversity: Current Status and Conservation Policies, Volume 1, Eds. Kumar., V., Kumar, S., Kamboj, N., Payum, T., Kumar, P. and Kumari, S. pp. 123-135, https://doi.org/10.26832/aesa2021-bdcp-08 